\title{
Strategies Producers in the Northeastern United States Are Using to Reduce Costs and Increase Profits in Tough Economic Times
}

\author{
Robin G. Brumfield ${ }^{1}$
}

ADDITIONAL INDEX WORDS. nursery, green industry, woody plant, floriculture, strategic planning, downturn, recovery, recession

SUMMARY. The environmental horticulture industry (sometimes referred to as the "green industry") is usually divided into nursery and floriculture crops. The green industry in the northeastern United States is an important component of agricultural production, with over $\$ 2$ billion in farm cash receipts, equating to $22.4 \%$ of all farm cash receipts in the northeastern United States. It is the number one agricultural commodity in five northeastern U.S. states. Competition in the green industry has become fierce. Many factors have put downward pressure on price. These include the recent volatility of fossil fuels and general energy prices, domestic competition, off-shore production, a weakened and stressed economy, and the growth of the mass market. Nationally, the number of producers continues to decline as a direct result of the newly defined economic risks. The industry's profit margins are typically low, leaving little room for growers to absorb significant increases in costs or decreases in revenues. Unlike farmers who produce field crops, nursery and greenhouse firms bear the entire price, market, and production risks because these crops have had no government support programs. This article will discuss what strategies producers in the northeastern United States are using to reduce costs and increase profits in tough economic times. It will analyze how producers have they honed their marketing and management skills to continue to survive and respond to current trends.

$\mathrm{T}$ The environmental horticulture industry (sometimes referred to as the green industry) is usually divided into nursery and floriculture crops. The U.S. floricultural and nursery industry is the second most important sector in U.S. agriculture in terms of economic output. The nursery and floriculture sectors have experienced considerable growth in the last two decades, albeit slowing somewhat in recent years. Nationally, green industry sales increased $13 \%$ from 2002 to 2007 , from $\$ 14.7$ billion to $\$ 15.5$ billion [U.S. Department of Agriculture (USDA), 2007d]. With the decline in the economy and housing construction, the industry is experiencing economic challenges not seen in recent decades. Currently, growers are faced with financial uncertainty, rising input costs, but flat prices, consumer economic fears, an increasingly global and complex market, growing public concern about chemicals and water pollution, slow housing starts, and

Professor and Specialist in Farm Management, De partment of Agriculture, Food, and Resource Economics, Rutgers University, New Brunswick, NJ 08901

${ }^{1}$ Corresponding author. E-mail: Brumfield@aesop. rutgers.edu. a maturing market. Competition in the green industry has become fierce. Many factors have put downward pressure on price. These include the recent volatility of fossil fuels and general energy prices, domestic competition, off-shore production, a weakened and stressed economy, and the growth of the mass market. The industry has seen consolidations and even bankruptcies. The business survival of many producers may be at risk.

Nationally, the number of producers continues to decline and is exacerbated by the newly defined economic risks. The 2007 Census of $\mathrm{Ag}$ riculture counted 50,784 operations with sales from horticultural crops, down 9\% from the 2002 Census of Agriculture (USDA, 2007a). The greenhouse and nursery industry in the northeastern United States is an important component of agricultural production with over two billion in farm cash receipts. It is the number one agricultural commodity in five northeastern U.S. states. Sales from the green industry comprise $5.6 \%$ of the total value of agricultural products sold in the United States (USDA, 2007b, $2007 \mathrm{c}$ ) and $21.2 \%$ of the total value of agricultural products sold in the northeastern United States (USDA, 2010).

One may argue that the impacts of the mass marketing of nursery and floricultural crops has been to reduce the number of growers while increasing the overall size (USDA, 2008) and mechanization of individual operations. The capital requirements (pot fillers, transplanters, mobile benches, pot spacers, and automated packaging and shipping), increased input costs (e.g., fuel, plastics, fertilizers, chemicals, and equipment), reduced margins, increased demands from buyers, and the market power associated with fewer numbers of buyers have all created intense market pressures and heightened competitive rivalry among producers. The industry's profit margins are typically low, leaving little room for growers to absorb significant increases in costs or decreases in revenues. Thus, many growers are challenged to produce an aesthetically pleasing, profitable, and socially responsible crop while decreasing costs and increasing efficiency of production practices.

Floriculture and nursery operations in the United States have traditionally been located near population centers, and currently tend to be concentrated in coastal areas (USDA, 2007a).This includes the northeastern United States with its large population of fairly high-income consumers. The green industry is the leading sector in agricultural in New Jersey and four other northeastern U.S. states (Connecticut, Massachusetts, New Hampshire, and Rhode Island) where heating cost is a concern (Table 1 ). The total cash value for this agricultural sector for the northeastern United States is over $\$ 2$ billion, equating to $12.1 \%$ of all farm cash receipts for the green industry across the country.

Unlike farmers who produce field crops, floricultural and nursery

\begin{tabular}{llll}
\hline $\begin{array}{l}\text { Units } \\
\begin{array}{l}\text { To convert U.S. to SI, } \\
\text { multiply by }\end{array}\end{array}$ & U.S. unit & SI unit & $\begin{array}{l}\text { To convert SI to U.S., } \\
\text { multiply by }\end{array}$ \\
\hline 0.4047 & acre(s) & ha & 2.4711 \\
2.54 & inch(es) & cm & 0.3937
\end{tabular}


Table 1. Greenhouse and nursery farm cash receipts for the 12 states that are located in the northeastern U.S. (USDA, 2010).

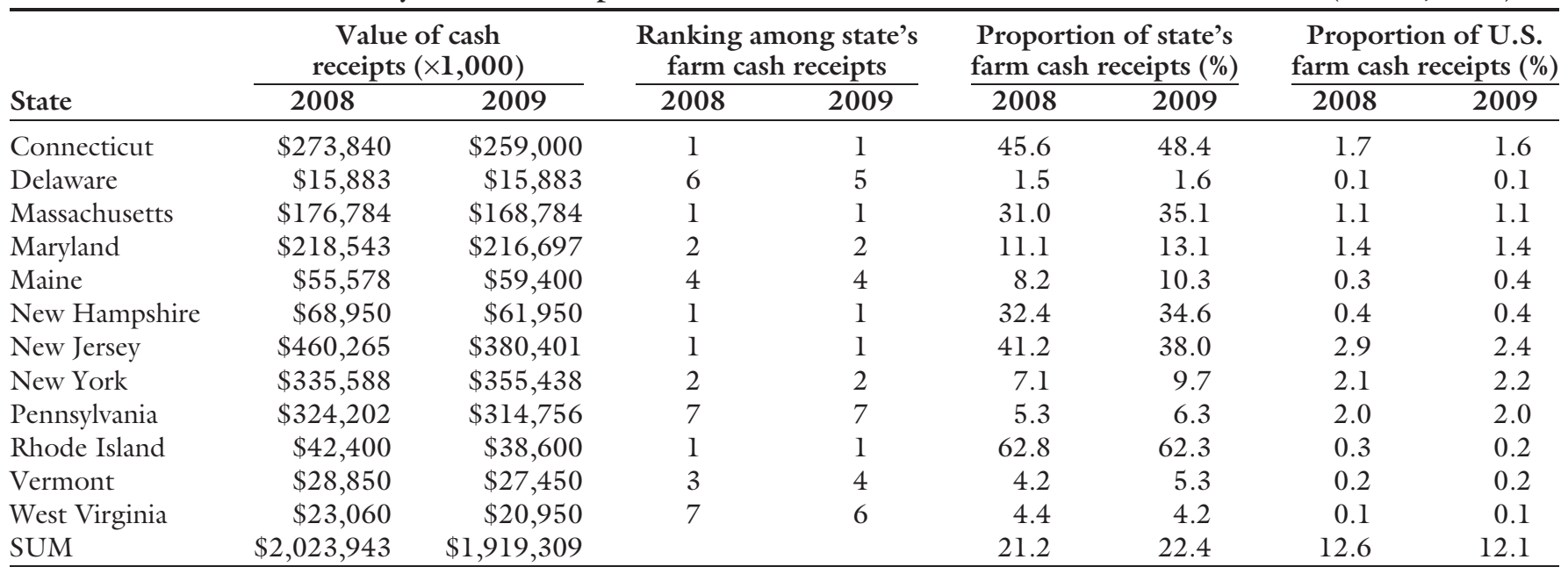

firms bear the entire price, market, and production risks because these crops have had no government support programs. Thus, to stay competitive, producers must develop their own risk management strategies. This article will discuss what strategies producers in the northeastern United States are using to reduce costs and increase profits in tough economic times. It will analyze how producers have they honed their marketing and management skills to continue to survive and respond to current trends.

\section{Strategic planning}

Each firm possesses a unique bundle of resources. Successful managers use these resources to develop their basic and special core competences that give them a comparative advantage. The best producers are engaging in strategic planning for their business. This can include a SWOT (strengths, weaknesses, opportunities, and threats) analysis, a strategic planning tool to help managers identify objectives and evaluate whether they are attainable (Friesner, 2010). This is done by first defining objectives of the firm and then assessing strengths, weaknesses, opportunities, and threats to develop strategies to meet those objectives. Strengths and weaknesses are internal characteristics of a businesses such as location, skills of key employees, and cash flow position. Successful firms consider the external forces in the industry, many of which are currently negative. Threats are the negative external forces that inhibit the firm's ability to achieve its objectives, while opportunities are positive external factors that the firm can employ to accomplish its objectives.
Building a successful business requires magnifying strengths and overcoming weaknesses. Once they identify strengths to build on and weaknesses to correct or overcome, producers can identify competitive advantages by matching internal strengths of the business to external opportunities. They try to overcome internal weakness and external threats by converting them into strengths or opportunities. An example of a conversion strategy is to find new markets. For example, many smaller growers who cannot compete on price with larger competitors have turned to direct marketing where they can compete on non-price factors such as service. If the threats or weaknesses cannot be converted, successful producers try to minimize or avoid them. For example, with housing starts reducing the market for larger trees and shrubs, many successful nurseries have focused on perennials and annuals that have lower price tags than trees and shrubs and still have a market in a depressed economy. Others try to find a unique product that others are not producing, like an unusual plant, or a variation on a common plant, like poinsettia (Euphorbia pulcherrima) trees instead of poinsettias in 6-inchdiameter pots.

In competing in the current economic climate, successful producers define where their organization is going by focusing on core competencies that lead to competitive advantages. They anticipate and take advantage of business trends. They align the firm's activities to the market position and anticipate the reaction of competitors. Instead of just reacting in the short run, they look at a long-term time horizon. To insure that they meet their objectives, they set up a system to measure the progress of meeting their objectives. A strategic plan needs to be frequently monitored and corrected to develop a new and revised strategy that includes an assessment of the present situation as well as an evaluation of current products, services, and marketing strategy. This may mean the objectives need to change.

The northeastern United States has some unique strengths. Perhaps the biggest advantage is that it is close to the market (i.e., located near a densely populated consumer market of high-income consumers). This gives them a comparative advantage over competitors who must pay shipping costs to reach this market, and it also gives them direct access to the customers to determine their wants and needs. Producers in the northeastern United States have a diversity of products, with 800 to 1500 different plants, whereas European producers have only two to three different plants (J.R. Johnson, personal communication). They also offer a full range of product lines. This allows them to adapt to a changing market. Perennials and annuals are the current winners. Nursery managers are moving woody plants into large pots to hold them for when the market improves. Many northeastern U.S. producers offer value-added products to capture more of the consumer dollar. As competition increases, producers look for new and unique varieties to differentiate their products from the competitions'. Trademarked lines, including private labels and industry-wide brands, help producers differentiate their products. 
Weaknesses for northeastern U.S. producers include some of the highest costs in the nation for land, labor, and other inputs. To overcome these economic weaknesses, producers must find ways to reduce costs to overcome these weaknesses or they must focus on their strengths or a combination of both.

\section{External opportunities and threats}

The recession was a threat to all businesses in the United States at the end of 2008 and through 2009. As would be expected, in 2009, the landscaping portion of the industry was hurting, as were sales of large trees and shrubs. For many businesses, weather proved to be a bigger challenge than the weak economy. Rainy weekends kept buyers away. Producers in New Jersey identified their greatest challenges to business expansion as owner/operator age, availability of capital, supermarket chains, competition costs, customers, deer/groundhogs, the economy, energy prices, insurance, labor, land, long hours, marketing, market saturation, regulations, relocation, resources, time, water issues, and weather (Brumfield et al., 2003).

The biggest opportunity for northeastern U.S. producers is that they are close to large consumer markets. There is also a "buy local, buy green" trend that fits well with the green industry.

\section{Finding their market niche: Matching strengths to opportunities}

In spite of the recession, some opportunities exist for northeastern U.S. producers. Innovative producers find a market niche that competitors are not serving. Buying local is a national trend, and northeastern U.S. producers are poised close to a large consumer market to take advantage of this opportunity. Green and sustainable is strong, and producers who can become green and offer consumers a sustainable alternative can thrive. In 2009, energy costs were high, making shipping costs an issue for west coast competitors. To make a profit, west coast producers needed to ship a full truck load of products. Northeastern U.S. producers could send small loads and make more frequent deliveries to better service their customers. Other producers are looking for differentiated products that meet consumer needs. An example is Plainview Growers (Pompton Plains, NJ), who began a line of pet greens to sell at pet stores. Vegetable transplants are strong anytime there is a downturn in the economy, as producers try growing some of their own food. This also ties in with the local and green movements. Unfortunately, home gardeners in the northeastern United States faced a frost late in May 2009 at the beginning of the growing season, and late blight on tomatoes later in the same season. This may have discouraged many new home gardeners. Producers will need to develop a marketing program to help these new gardeners succeed in 2010.

\section{Listening carefully to what the customer wants}

A key in today's competitive market is listening carefully to consumers. Gone are the days when growers could produce their favorite crops and expect them to sell themselves. We have switched from a producer-driven to consumer-driven market.

Everyone and every company have a brand. The brand is their reputation. A salesperson in a retail greenhouse or garden center or a merchandiser in a big box store has more impact on a company's reputation than anyone in management. They have the relationship with the consumer. They are the ones who take the time to listen to the customers and help them load their car with green industry products. Businesses that do really listen to customer requests directly or via employee feedback, and actually implement their suggestions, can create consumer loyalty and profits. This was verified in a survey of over 2000 companies that ranked them from the most to the least successful, and compared the approaches of the "winners" or "most successful" with the "losers" or "less successful" to isolate the factors that make a difference (Coulson-Thomas, 2007). The results suggest that most of the critical success factors are attitudinal and behavioral. The "less successful" companies are unsure and unaware of the needs of others. They are cautious and fail to inspire and motivate. Losers are also reactive. They respond to events and often fail to anticipate the need for change. They confuse operational with strategic business issues. They fail to notice what is important and the biggest opportunities for performance improvement. On the other hand, winners tend to have a longerterm perspective. They are confident, positive, and proactive. They create compelling visions. They encourage innovation, trust other people, and share information and opportunities with them. They understand their customers and concern themselves with increasing customer retention. Winners value relationships, empathize, ask for feedback, and are good listeners. Winners then, transform and re-invent, and recognize that change can be stressful and can disrupt valued relationships. This applies not only to customers, but to valuing employees.

Because producers in the northeastern United States face higher costs than producers in other parts of the countries, they must focus on strategic planning to use their strengths. Producers try to understand their customers and retain them. Retail producers have frequent communication with them, and wholesale producers work with retailers to determine what the customer wants. Many of them use surveys, social media, and special efforts to determine the consumers' wants, and then develop a product (and package) that satisfies those wants. This applies to wholesale and retail markets.

In addition to building comprehensive websites and generating enewsletters, growers are increasingly getting involved with social media via Facebook and Twitter. The idea is to build that one-to-one customer relationship and communicate more often. It is an attractive alternative or supplement to cost-intensive printed promotions and catalogs. This keeps the consumer more engaged their business and products. They tie their websites to their social media sites to reach consumers and to get feedback from them. Many retail producers provide extensive care and diagnostic information, as well as what is available now on their websites.

Products must satisfy the consumer's needs: the features, service aspects, marketing season, and benefits to the buyer whether that is the consumer who comes to a retail nursery to buy their perennials, or the wholesaler who is buying annual vincas (Catharanthus spp.) to sell to 
garden centers. With pay-by-scan, wholesale growers have merchandisers at retail stores to display products. Because the merchandisers see what products are moving and hear what customers are saying, they can provide valuable marketing information to the manager.

U.S. demographics are changing. The number of mature consumers and tech-savvy younger customers who care about sustainability are increasing. The United States is becoming more ethnically diverse. For the first time in history, more women are in the workforce than men. These changing demographics are driving changes in consumer demand for green industry products. Today's recession-worried consumer is looking for quality, variety, and value. Some consumers need or want good price deals and will search for lower prices. This means that producers must supply the products that consumers want, and keep production costs low. An example of developing the product that would make it more convenient and add value in the eyes of the consumer are the mixed containers, once targeted to apartment dwellers, but now also popular with owners of single family homes. Customer service is key. The worse the economy, the better the quality must be.

\section{Knowing their costs: Focus on cost control}

Increasing costs of inputs are one of the biggest challenges to growers. Input costs-energy, labor, containers, soil amendments, fertilizer, chemicals, labels, tags, and plastic-are all increasing, but consumers expect price stability or reductions during the recession. This cost-price squeeze has the effect of reducing profit margins. This is especially crucial for mediumsized growers, who do not have the flexibility of small growers and the economics of size of larger ones. With the tight margins, managers must do cost accounting and control their costs. Producers are becoming more interested in benchmarking (Behe et al., 2008; Brumfield, 2009; Hall et al., 2006). Demand for the Rutgers Cost Accounting Program has increased dramatically during the recent recession, and more producers are accessing the free version on line (Brumfield, 2008a). As demand grows for the Rutgers Cost Accounting Program, so do requests from producers for more features. As a result of listening to these requests and changing the program to respond to these requests, the program now allows producers to also do cost accounting for outdoor crops as well as greenhouse crops. In additions, the program now has a section that calculates key financial ratios, which allows producers to benchmark their progress against their own business year to year (Brumfield, 2008b).

Partnering with other producers, cooperatives, suppliers, or companies is one way some producers have cut costs. They partner with others to produce product, purchase inputs, or market their products. If they find that they can buy good quality product from a competitor, they purchase in that product and focus on producing plants that are unique to them.

\section{Reduce energy costs}

The input cost weighing most heavily on growers is energy. In 2003 , the average greenhouse in New Jersey spent $5.3 \%$ of sales on heating fuel (Brumfield, 2007) and had profits of $9.4 \%$ of sales. Fuel oil, the typical fuel used to heat greenhouses almost tripled in price from 2003 to the middle of 2008 , but has since come down to levels experienced during the middle of the decade (U.S. Department of Energy, 2009). If, as expected, oil prices start to climb again, a typical commercial greenhouse operation would experience significant difficulty making a profit, and the industry would be in peril. Remembering the energy crisis of the 1970s, there are significant parallels, but also some significant differences. The general consensus remains that fossil fuels represent a finite supply that must eventually be replaced with sustainable energy resources and that it is prudent for our country to take steps to free itself from its dependence on foreign oil. Growers applied an assortment of ideas to reduce energy costs, including extensive greenhouse winterization, applying new heating methods, and installing new, more efficient boilers.

\section{Energy-saving technologies}

In a 2003 survey of New Jersey greenhouses, $61 \%$ of the respondents were considering energy-saving technologies (Brumfield et al., 2003). In
2008 survey of New Jersey greenhouses, $45 \%$ of the respondents had actually implemented energy-saving technologies since 2003 and $39 \%$ are considering implementing energy-saving technologies (Brumfield et al., 2009a). Growers had implemented an assortment of ideas to reduce energy costs. The most common were energy curtains (11\%), lower set point temperatures $(9 \%)$, bottom heat $(7 \%)$, and closing down a portion of the year $(7 \%)$. Wood boilers $(5 \%)$, new coverings $(5 \%)$, growing in less space $(5 \%)$, new heaters $(5 \%)$, tightening the greenhouse $(4 \%)$, new wall materials $(2 \%)$, new equipment $(2 \%)$, environmental control computers $(2 \%)$, changing to hardy plant crops (2\%), new thermostats $(2 \%)$, and pad and fan cooling $(2 \%)$ were energy-saving technologies that some growers had adopted since 2003.

The 2008 energy survey, in an open-ended question, asked producers who were considering energysaving technologies what technologies they were considering. Solar (14\%) and wind $(13 \%)$ were the most frequently mentioned energy-saving technologies respondents were considering. While solar and wind are alternative energy sources, and not usually thought of as energy-saving technologies, presumably, producers were thinking of fossil fuels as the type of energy they wanted to save. Nine percent of respondents were not sure what energy-saving technologies to adopt, but were considering all options. While as mentioned above, $45 \%$ of the 2008 respondents had implemented energy conservation measures since 2003 , some of them were still considering implementing energy conservation measures. Energy curtains $(7 \%)$, wood-burning furnaces $(7 \%)$, more efficient heaters / boilers $(4 \%)$, alternative heat source $(2 \%)$, rigid plastic walls $(2 \%)$, geothermal $(2 \%)$, and fuel pre-heaters (2\%) are other energy-saving technologies that producers were considering in 2008 .

\section{Alternative energy}

Modest oil prices following the early energy crisis and through the 1990s have shifted much of the attention away from increased self-reliance and/or the development of alternative energy sources, but recent volatility of oil prices has prompted some growers to consider alternative energy sources. 
A 2008 survey of New Jersey greenhouse growers showed that while only $4 \%$ have adopted alternative energy, $45 \%$ of them are investigating new methods of energy use, storage, and generation. Some of the alternative energy uses include biomass [wood, corn (Zea mays), switchgrass (Panicum virgatum), etc.], co-firing (coal and biomass), solar, wind, groundsource heat pumps, and geothermal (Brumfield et al., 2009a). Arie Van Vugt, owner of Plainview Growers, is involved in a research project with Rutgers researchers that will investigate the economical utilization of perennial grass biomass as a fuel source for heating greenhouses. Pequest Energy, a newly established renewable energy company, also owned by A. Van Vugt, will sell biomass pellets to local businesses and consumers looking to use renewable energy. The venture will make the cost of the energy predictable, as well as offer several other advantages for greenhouse managers who chose to produce their own energy. Most northeastern U.S. greenhouses are seasonal businesses, with maximum production in the spring. Adding energy production to their businesses will help spread their overhead costs over more of the year, as well as extend employment opportunities. For example, Plainview Growers truck drivers will be transporting biomass from local farms to the processing facility from November through February, months in which they normally transport few greenhouse products. Other employees normally not working in the greenhouse during these months will be involved in the processing and pelletizing of the biomass. Smaller growers who do not want to invest in the capital equipment required to pelletize biomass can have Pequest Energy pelletize it for them for a fee. Or, if they simply want to farm and not take market risks, they can function as contract growers and sell their biomass crops to Pequest Energy. Pequest Energy is working with local row crop farmers and hay producers to buy their switchgrass for pelletizing. Some of these farmers manage land planted with warm-season perennial grasses for wildlife habitat, and selling the biomass will give them an outlet for their biomass, thus providing an additional source of income. In addition to economic benefits to individual producers, establishment of a commercially viable use of cellulosic biofuels can potentially reduce the environmental costs of fossil fuels, which include global warming, pollution, and habitat destruction; the security costs of protecting our oil supply; and the economic costs of oil subsidies, negative impact on our balance of trade, and our vulnerability to volatility of foreign oil prices (Greene et al., 2004).

\section{Invest in people: Employees and customers}

People are the most valuable asset in the green industry - the customers and employees. Without customers, there is no business, and the same can be said for employees. Successful producers encourage their best employees and promote an environment that makes these employees never want to leave. This includes things like including employees as part of the management team, giving them responsibilities, and rewarding them for success. This works with family and non-family members. Managers who delegate responsibilities to their employees and allow them to obtain more and more responsibility and reward keep good employees. On the other hand, managers who do not delegate responsibilities to their good employees see them leave the business, whether they are family members or not. Labor has traditionally been the highest cost faced by nursery and greenhouse producers (Brumfield, 2008). It may be tempting to hire cheap labor, but it is much cheaper and more profitable to keep good employees than to train new ones. Investing in cutting edge improvements in technology can decrease labor costs, but someone has to manage the technology and interface with customers; people are still needed. Leading producers know that a satisfied employee who feels part of the team is the strongest investment a company can make. Listening to employees and implementing their ideas in the same way good managers listen to customers show employees that they are valued. Another way more and more producers are making employees feel valued is to keep them employed yearround. Lucas Greenhouses, owned by George and Louise Lucas in Monroeville, NJ, has emerged as one of the fastest-growing, well-diversified operations in the United States, and a key to their success is investing in people. They are ranked at number 90 on Greenhouse Growers Magazine Top 100 Growers list, and they believe in investing in people. "George and Louise Lucas just seem to bring out the best in everyone they interact with, whether it is nurturing employees, partnering with fellow growers, learning with suppliers or going the extra mile to serve independent garden centers. They set high standards through their actions, dedication and hard work. Their faith, honesty, and trust inspires you to be the best you can be" (Onofrey, 2009).

\section{Produce year round: Spread fixed costs over more output}

One method commonly used by nursery and greenhouse firms to reduce overhead costs is to add new crops or enterprises to keep their business going year round. This creates efficiencies by spreading the fixed costs over more output. Few producers produce and sell only greenhouse or nursery products. More and more producers are adding enterprises that allow them to remain in business year round. They have added everything from growing vegetables, Christmas trees, switchgrass, or other crops to use their facilities and labor much of the year. Producers are changing products and marketing channels to fit the changing market.

\section{Integrate horizontally: Control more of the market}

The goal of horizontal integration is not to control all aspects of production, from raw materials to the final product. It is, instead, to be able to produce a large number of the same product or similar products and to control a large share of the market. One way to integrate horizontally is to buy a second business, or expand to a second location to capture more of the market and create economies of scale. In a recessionary economy, successful firms can acquire struggling rivals cheaply. An example of this is Dan Schantz Greenhouses in Allentown, PA, who successfully bought a bankrupt Frank's garden center location, and turned it into a second, profitable outlet for their products, and expanded their market in the process.

Horizontal integration brings many advantages to those businesses 
that are able to effectively expand. However, if a company expands horizontally too quickly without a solid plan, it can quickly be overwhelmed in several ways, including financially, managerially, excessive capacity, and excess inventory. Bigger is not always better. The expansion requires extra management and often a shift from the owner being an entrepreneur who developed a small business and made all of the managerial decisions to a manager who must delegate responsibilities to others within the firm. Unused capacity from buying another business can lead to problems such as excessive overhead costs. Overproduction without a market can lead to increased costs and excessive shrink, which can erode profits. On the other hand, with a carefully planned horizontal expansion, firms are able to sell more of their products, which is usually the goal of any company. Controlling a larger share of a given market gives a business greater power over the flow of products and resources from other companies. All of this added control, power, and productive ability add to the effectiveness of the business through economics of scale. With the proper planning, though, horizontal expansion can lead a business to great rewards.

\section{Vertically integrate the business: Make buying an experience}

Vertical integration has a goal of controlling all aspects of the production of a product or service. The most common form of vertical integration in the green industry in the northeastern United States is to add a direct marketing component. Dryers Farm has effectively used vertical integration to take advantage of their comparative advantages. The Dryers were wholesale vegetable farmers in Cranford, NJ. Cranford has been transformed from a lazy suburb to a bedroom commuter city for New York City Wall Street executives. Land is now extremely expensive and labor costs are high. But, rather than selling out to development, Dryers' now retails their products yearround. They sell fresh, local, in-season produce, flowers, pumpkins (Cucurbita moschata), Christmas trees, perennials, etc. They offer variety and "value added" to high-income consumers who want to buy locally. Another advantage is that they can maintain their work force most of the year. This allows them to better manage their labor, and not hire as many extra seasonal employees.

Often adding direct marketing includes a degree of entertainment for the customer, making the farm a destination. In New Jersey and across the United States, agritourism is emerging as an important strategy for bolstering farm profitability. Agritourism is broadly defined as the business of establishing farms as travel destinations for educational and recreational purposes. Activities include hayrides, corn mazes, pick-your-own produce, farm stands, school tours, farm festivals, and winery tours.

A Rutgers study found that more than one-fifth of New Jersey farms offer some form of agritourism, $43 \%$ of New Jersey's total farmland associated with farm operations is engaged in agritourism, and $60 \%$ of farms involved in agritourism offered floral products (Schilling et al., 2006). The popularity of agritourism reflects the fact that it offers benefits to farmers and the public by generating additional income, enabling farmers to diversify product lines and markets, and raising awareness and understanding of our agrarian heritage, food production, and resource stewardship. In addition to revenues for farmers, the Rutgers study found that for every dollar in agritourism sales generated on a farm, $\$ 0.58$ of additional sales are generated in a wide range of other allied businesses, such as restaurants, construction companies, and insurance providers. Therefore, agritourism created an additional $\$ 33.3$ million in revenue in other nonfarm businesses in 2006. That, together with the on-farm revenue, brought the revenue impact of agritourism to the state to almost $\$ 91$ million in 2006. Other key findings in the survey included: 1) the average agritourism income reported by farms with agritourism activities was $\$ 27,093$ in $2006 ; 2) 36 \%$ of farms with agritourism earned $100 \%$ of their total farm income from agritourism; 3 ) $52 \%$ earned at least half of their farm income from agritourism; and 4) 19\% of farms reporting agritourism did not earn any revenue from agritourism activities, finding value in the opportunity to engage in interactions with the public that promote awareness, appreciation, and understanding of agriculture.

\section{Abandoned competing in the "lowest price" market}

Big box stores are here to stay, are the price setters, and continue to push prices down. Some northeastern U.S. producers successfully compete in this market by controlling costs and inventory. Most, however, do not compete in the "lowest price" market. Instead, they sell to independent garden centers, or directly to consumers. They focus on new and unique products or services where they can offer their consumers value. They look for areas where they can outshine the competition in things like direct marketing, agritourism, new and unique varieties and enterprises, product appearance, and accuracy-for example, some of the most successful wholesale greenhouses who sell plugs to other growers guarantee a high number of plugs in each tray, performance, ease/ cost of installation-this can include features like biodegradable pots, price, ease/cost of training, versatility, ease/ cost of use, durability, ease/cost of maintenance, speedy delivery, trademarked lines, their own or industrywide, quality, diversity of products, and a full range of product lines.

\section{Reduce risks}

In this scary economy, businesses are looking for ways to reduce risks. They are reviewing their life insurance, disability insurance, health insurance, and crop, fire, wind, hail, and liability insurance. Crop insurance participation in the 12 northeastern states (Connecticut, Delaware, Maine, Maryland, Massachusetts, New Hampshire, New Jersey, New York, Pennsylvania, Rhode Island, Vermont, and West Virginia) has steadily increased over the past few years. Over 3.4 million acres were covered by nursery crop insurance in 2008. A minimum level of crop insurance, catastrophic insurance (CAT), is available to all producers, regardless of size, at no premium costs to the producer because CAT premiums are paid by the federal government. Higher levels of crop insurance (buy-up protection) are also federally subsidized, with nursery growers paying only $33 \%$ to $45 \%$ of the actual cost of the insurance. Nursery crops accounted for about $15 \%$ of the total value of crop insurance protection in force in the northeast in 2008. Over $\$ 232$ million of nursery plants were 
protected by crop insurance in 2008 (Harper and Brumfield, 2009).

Northeastern producers implemented financial management practices that would cut costs and improve the profitability at the current size before getting bigger. They considered ways to eliminate debt or restructure it. Many are evaluating cash flow and their line of credit. With the focus on sustainability, they have pesticide management plans, use integrated pest management (IPM), and are looking for more sustainable systems.

They are reviewing their estate plans. Most do not plan to retire, but they do want to plan for an income stream in their later years. As a result of focus group feedback, Rutgers developed a Later Life Farming website (O'Neill et al., 2009) to help farmers deal with producing income in retirement or in later years as they cut back on some activities or turn the business over to others (Brumfield et al., 2009b).

\section{Conclusions}

What have northeastern U.S. growers done to survive? The most successful ones were innovative and creative. They matched their firm's strengths and weaknesses to external opportunities and threats.

Producers are looking to rightsize their operation. They have learned that bigger is not necessarily better. Rather than constantly planning to expand their operations, some have actually reduced the size of their production area. They prefer to cut back on production, sell out, and dump less rather than overproducing plants that must be dumped.

Producers are communicating more frequently with their customers, and many are adding value and/or service. The weak economy has prompted many businesses to evaluate their pricing strategies. Some nurseries and greenhouses have lowered prices to reduce inventory. Others have cut back on production and destroyed product rather than lower price because they want to maintain their reputation as a producer of quality products, and not be known for cheap prices; they compost the plant material and save the potting media. Rather than dumping, some businesses are repotting unsold plant material into larger pots sizes and mixed containers for higher prices in the future.
Most are going back to the basics and staying true to their strengths and core values. They have returned to the products and services that make them unique. Customer service is key. The worse the economy, the better the quality must be. Retail growers are offering delivery services, loading and unloading, potting stations, packaging, advice, quality, value, convenience, social media access to customers, newsletters, and selection (relative to the competitor's). Wholesalers are offering user friendly websites, point of sale materials, pre-pricing programs, on-line ordering, early paying discounts, quantity discounts, and frequent deliveries.

Reducing costs is an important consideration no matter what type of competitive strategy they choose. This included a variety of strategies from growing their own fuel to cutting back on production, to managing their inventory more carefully. Some have integrated horizontally to spread their fixed costs over more output. Others have integrated vertically to take more of the consumer dollar. Successful northeastern U.S. producers invested in people, i.e., their employees and customers. They stayed informed about their customers' needs and desires.

While heating costs are high for greenhouse producers in the northeastern United States, having a location near a densely populated consumer market of high-income consumers has positioned northeastern U.S. growers well to compete with producers from other regions who face high transportation costs in reaching the northeastern U.S. market. Northeastern U.S. producers have honed their skills in marketing and management to enable the green industry to continue to survive and thrive there.

\section{Literature cited}

Behe, B.K., J.H. Dennis, C.R. Hall, A.W. Hodges, and R.G. Brumfield. 2008. Regional marketing practices in U.S. nursery production. HortScience 43:2070-2075.

Brumfield, R.G. 2007. Dealing with rising energy costs. Greenhouse Product News 17:24-31.

Brumfield, R.G. 2008a. Rutgers University interactive greenhouse crop budget with five crops. 8 May 2010. <http:// aesop.rutgers.edu/ farmmgmt/greenhouse/greenhouseinteractiveform.html>.

Brumfield, R.G. 2008b. A tool to help greenhouse managers take control of their greenhouse and outdoor costs. Southern Nursery Assn. Res. Conf. Proc. 53:32-37.

Brumfield, R.G. 2009. Increase your profits through benchmark analysis: Pulling your basic financial information together. Ohio Florists' Assn. Nwsl. 914: 24-28.

Brumfield, R.G., A.J. Both, and G. Wulster. 2009a. How are greenhouse growers coping with rising energy costs? Southern Nursery Assn. Res. Conf. Proc. 54:304307.

Brumfield, R.G., B. O’Neill, S.J. Komar, and R. Mickel. 2009b. Transferring the farm and creating a retirement "paycheck" from farm income and assets. Proc. 5th Natl. Small Farm Conf. 5: 204-207.

Brumfield, R.G., G. Wulster, and A.J. Both. 2003. New Jersey greenhouse survey. 10 May 2010. <http://aesop.rutgers.edu/ $\sim$ farmmgmt/ghsurvey/index.html $>$.

Coulson-Thomas, C. 2007. Winning companies: Winning people. Policy Publications. Cambridgeshire, UK.

Friesner, T. 2010. History of SWOT analysis. 10 Mar. 2010. <http://www. marketingteacher.com/SWOT/history_ of_swot.htm>.

Greene, N., F. Celik, B. Dale, M. Jackson, K. Jayawardhana, H. Jin, E.D. Larson, M. Laser, L. Lynd, D. Mackenzie, J. Mark, J. McBride, S. McLaughlin, and D. Saccaridi. 2004. Growing energy: How biofuels can help end America's oil dependence. National Resources Defense Council, New York.

Hall, C.R., A.W. Hodges, and J.J. Haydu. 2006. The economic impacts of the green industry in the U.S. HortTechnology 16: 345-353.

Harper, J.K. and R.G. Brumfield. 2009. Crop insurance for Northeast nursery and greenhouse crops. 11 May 2010. $<$ http://cropins.aers.psu.edu/FactSheets / 2009Nursery.pdf>.

O’Neill, B., S. Komar, R.G. Brumfield, and R.C. Mickel. 2009. Rutgers University later life farming. 8 May 2010. $<$ http://laterlifefarming.rutgers.edu/>.

Onofrey, D. 2009. Understated excellence: George and Louise Lucas combine the best in high tech and high touch by mixing modern production with momand-pop values. 10 May 2010. <http:// www.greenhousegrower.com/specialre ports / grower $/$ ?storyid $=2508>$. 
Schilling, B.J., L.J. Marxen, H.H. Heinich, and F.J.A. Brooks. 2006. The opportunity for agritourism development in New Jersey. Rutgers Univ. Food Policy Inst. Publ. No. 0706-010. 10 May 2010. <http:// www.nj.gov/agriculture/pdf/ATReport. pdf>.

U.S. Department of Agriculture. 2007a. Census of agriculture. 2007. Greenhouse, nursery, and floriculture operations. 2 Mar. 2010. <http://www.agcensus.usda.gov/ Publications/2007/Online_Highlights/ Fact_Sheets/nursery.pdf>.
U.S. Department of Agriculture. 2007b. Floriculture crops summary. 11 May 2010. <http://usda.mannlib.cornell.edu/ usda/current/FlorCrop/FlorCrop-04-232009.pdf>.

U.S. Department of Agriculture. 2007c. Nursery crops summary. 11 May 2010. <http://usda.mannlib.cornell.edu/ usda/current/NursProd/NursProd-0926-2007.pdf>.

U.S. Department of Agriculture. 2007d. Census of agriculture. State-level data: New
Jersey. 19 Mar. 2010. <http://www. agcensus.usda.gov/Publications /2007/ Full_Report/Volume_1,_Chapter_l_State_ Level/New_Jersey/index.asp>

U.S. Department of Agriculture. 2010. Economic Research Service. State Facts. 15 Sep. 2010. <http://www.ers.usda. gov/StateFacts/NJ.htm>.

U.S. Department of Energy. 2009. Annual energy outlook 2009. U.S. Dept. Energy, Washington, DC. 